\title{
PENGARUH METODE PROBLEM-BASED LEARNING DAN DIRECT TEACHING TERHADAP HASIL BELAJAR ALAT UKUR
}

\author{
Heru Raharjo \\ SMKN 1 Ngawen Gunungkidul \\ heru_pascauny@yahoo.co.id \\ Soenarto \\ Universitas Negeri Yogyakarta \\ soenarto@uny.ac.id
}

Abstrak

\begin{abstract}
Penelitian ini bertujuan mengetahui: (1) perbedaan hasil belajar siswa yang diajar dengan metode PBL dan direct teaching, motivasi belajar tinggi dan rendah, kreativitas tinggi dan rendah; (2) pengaruh interaksi antara metode pembelajaran dengan motivasi belajar dan kreativitas terhadap hasil belajar; (3) perbedaan hasil belajar siswa yang diajar dengan metode PBL dan direct teaching ditinjau dari motivasi belajar dan kreativitas. Penelitian ini merupakan penelitian eksperimen semu dengan desain faktorial. Analisis data yang digunakan adalah uji Anava dan uji-t. Hasil penelitian menunjukkan: (1) ada perbedaan hasil belajar antara siswa yang diajar dengan metode PBL dan direct teaching; (2) tidak ada perbedaan hasil belajar antara siswa yang memiliki motivasi belajar tinggi dan rendah; (3) ada perbedaan hasil belajar antara siswa yang memiliki kreativitas tinggi dan rendah; (4) ada pengaruh interaksi antara metode pembelajaran dengan motivasi belajar terhadap hasil belajar; (5) ada pengaruh interaksi antara metode pembelajaran dengan kreativitas terhadap hasil belajar; (6) ada perbedaan hasil belajar antara siswa yang diajar dengan metode PBL dan direct teaching ditinjau dari motivasi belajar; (7) ada perbedaan hasil belajar antara siswa yang diajar dengan metode PBL dan direct teaching ditinjau dari kreativitas.
\end{abstract}

Kata Kunci: Problem-Based Learning, Direct Teaching, Motivasi Belajar, Kreativitas

\section{THE EFFECT OF PROBLEM-BASED LEARNING AND DIRECT TEACHING METHOD ON LEARNING OUTCOMES OF MEASURING TOOLS}

\begin{abstract}
This study aims to investigate: (1) the difference of learning outcomes between students taught using $P B L$ and direct teaching method, high and low motivation, high and low creativity; (2) the effect of interaction between learning method, motivation and creativity on learning outcomes; (3) the difference of learning outcomes between students taught using PBL and direct teaching method in terms of motivation and creativity. This is quasy-experimental research with a factorial design. Data were analysed statiscally using Anava and t-test. The result shows that: (1) there was difference of learning outcomes between students taught using PBL and direct teaching method; (2) there was no difference of learning outcomes between students who have high and low motivation; (3) there was difference of learning outcomes between students who have high and low creativity; (4) there was interaction effect between learning method and motivation on learning outcomes; (5) there was interaction effect between learning method and creativity on learning outcomes; (6) there was difference of learning outcomes between students taught using PBL and direct teaching method in term of motivation; (7) there was difference of learning outcomes between students taught using $P B L$ and direct teaching method in term of creativity.
\end{abstract}

Keywords: Problem-Based Learning, Direct Teaching, Motivation, Creativity 


\section{PENDAHULUAN}

Sekolah Menengah Kejuruan (SMK) mempunyai misi mendidik calon tenaga kerja tingkat menengah yang memiliki kemampuan sesuai dengan yang dibutuhkan dunia kerja. Siswa SMK harus memahami proses kerja, situasi, dan lingkungan kerja di mana mereka nantinya akan bekerja. Keberhasilan pendidikan kejuruan tidak hanya diukur oleh prestasi akademik siswa di sekolah semata, akan tetapi diukur oleh prestasi kerja di dunia kerja setelah mereka lulus. Untuk itu kurikulum yang dikembangkan di SMK harus mengikuti perkembangan dan sesuai dengan tuntutan dunia usaha/dunia industri (Finch \& Crunkilton, 1999,p.14).

Selain itu, siswa SMK diharapkan mempunyai motivasi yang tinggi untuk mencapai keberhasilan belajar. Siswa juga diharapkan memiliki kreativitas sehingga akan menjadi pribadi yang kreatif dan berwawasan terhadap masa depannya. Pada kenyataannya siswa mempunyai motivasi dan kreativitas yang berbeda-beda pada pembelajaran di sekolah. Perbedaan ini memerlukan perlakuan yang berbeda pula pada masing-masing siswa.

Hal yang lebih spesifik terjadi di SMKN 1 Ngawen Gunungkidul adalah walaupun sekolah sudah mempunyai data mengenai tingkat motivasi dan kreativitas dari hasil tes masuk siswa baru akan tetapi sekolah belum mengoptimalkan melalui proses belajar mengajar (PBM). Bahkan hasil belajar siswa untuk pelajaran produktif masih rendah. Salah satu pelajaran produktif yang masih rendah nilainya adalah pelajaran alat ukur.

Tabel 1. Persentase Nilai Ujian Utama Kompetensi Alat Ukur

\begin{tabular}{lcc}
\hline Kelas & $<$ KKM & $\geq$ KKM \\
\hline X OA & $37.5 \%$ & $62.5 \%$ \\
X OB & $43.75 \%$ & $56.25 \%$ \\
X OC & $28.125 \%$ & $71.875 \%$ \\
X OD & $37.5 \%$ & $62.5 \%$ \\
\hline
\end{tabular}

Hasil dokumen nilai ujian utama kompetensi menggunakan alat ukur pada tahun pelajaran 2011/2012 didapatkan bahwa masih banyak siswa yang belum mencapai kriteria ketuntasan minimal (KKM). Tabel hasil belajar alat ukur berdasar batas KKM dapat dilihat pada tabel 1. Siswa yang belum mencapai KKM harus mengikuti remedi. Pelaksanaan remidi ini tentu membutuhkan waktu dan pemikiran baik bagi guru maupun sekolah.

Perolehan hasil belajar yang masih banyak di bawah KKM ini dipengaruhi oleh beberapa faktor, salah satunya adalah metode pembelajaran yang diterapkan oleh guru. Metode pembelajaran merupakan serangkaian cara atau strategi yang disusun untuk menciptakan kondisi pembelajaran agar berlangsung sesuai dengan yang diharapkan, siswa dapat meningkat keaktifannya dalam proses pembelajaran dan menghasilkan hasil belajar yang baik, Joyce, Weil \& Calhoun (2009,p.7); Parkay \& Stanford (2010,p.66).

Pembelajaran dikatakan efektif jika menerapkan PBM yang dapat meningkatkan aktifitas belajar siswa dan menghasilkan hasil belajar yang optimal. Efektifitas pembelajaran dapat diukur dari kemampuan siswa dalam menerapkan pengetahuan yang diperolehnya (Guthrie \& Schuerman, 2011,p.51) dan (Wong \& Wong, 2005,p.199).

Salah satu metode pembelajaran berbasis pada siswa yang mampu meningkatkan hasil belajar siswa adalah metode pembelajaran problem-based learning (PBL). Metode PBL adalah metode pembelajaran dengan menghadapkan siswa pada permasalahanpermasalahan yang nyata sehingga dari permasalahan tersebut siswa dapat meningkatkan pengetahuan dan pemahamannya (Liu, Liau \& Tan, 2009,p.206); Marsh (2010,p.211); Baden \& Major (2004,p.4). Senada dengan hal tersebut, Wood (http:dx.doi. org/10.1136/bmj.326.7384.328) menyatakan:

PBL is not about problem solving per se, but rather it uses appropriate problems to increase knowledge and understanding

PBL bukanlah sekedar pemecahan masalah, tetapi menggunakan masalah yang berkait untuk meningkatkan pengetahuan dan pemahaman. PBL merupakan pembelajaran aktif, progresif berpusat pada masalah yang tidak terstruktur yang digunakan sebagai titik awal dalam proses pembelajaran. PBL sering dilakukan 
dengan pendekatan tim melalui penekanan pada pembangunan keterampilan yang berkaitan dengan pengambilan keputusan, diskusi, pemeliharaan tim, manajemen konflik, dan kepemimpinan tim.

PBL merupakan metode pembelajaran yang menantang siswa agar belajar untuk belajar, bekerja sama dengan kelompok untuk mencari solusi atas permasalahan yang nyata dan permasalahan digunakan untuk meningkatkan rasa keingintahuan serta kemampuan kritis dan analisis atas materi pelajaran.

Langkah-langkah pembelajaran PBL dimulai dengan penemuan masalah yang dirancang oleh guru kemudian siswa melakukan kegiatan pembelajaran dengan mencari informasi dari berbagai sumber, diskusi kelompok, praktek penyelidikan dalam rangka menemukan permasalahan dan mencari solusi sehingga dari proses tersebut siswa dapat menemukan pengetahuan baru. Sintaks metode pembelajaran PBL terdiri atas lima tahapan, yaitu: (1) memberikan orientasi permasalahan; (2) mengorganisasi siswa untuk meneliti, (3) membantu investigasi mandiri dan kelompok; (4) mengembangkan dan mempresentasikan artefak; dan (5) menganalisis dan mengevaluasi proses mengatasi masalah (Arends, 2008); (Suprijono, 2010) dan (Tan, 2003).

Metode pembelajaran direct teaching adalah pembelajaran yang diterapkan oleh guru untuk memindahkan pengalaman dan informasi kepada siswa dengan memberikan keterangan terlebih dahulu, definisi, prinsip dan konsep materi pembelajaran serta memberikan contoh-contoh soal dalam bentuk ceramah, penugasan, diskusi dan jawab dari materi pembelajaran (Marsh, 2010,p.209); Parkay \& Stanford (2010,p.347).

Metode pembelajaran direct teaching memiliki karakteristik: (1) berpusat pada guru; (2) mengharuskan kehadiran guru; (3) siswa menerima apa yang disampaikan guru; (4) tujuan pembelajaran disampaikan di awal pertemuan; (5) cocok untuk materi yang berupa pengembangan dasar; dan (6) tidak cocok untul materi pelajaran yang tidak terstruktur.

Motivasi belajar adalah suatu perubahan energi yang terdapat pada diri siswa yang mendorong siswa untuk melakukan hal yang ingin dicapai, sesuatu yang membuat siswa tersebut tetap ingin melakukannya dan menyelesaikan tugas-tugas akademik (Mc Lean, 2009,p.7); (Woolfolk, 2007,p.372); (Galton, et al., 2009,p.9).

Indikator untuk mengukur motivasi belajar yang dikemukakan oleh Sardiman (2011,p.83) meliputi: (1) ketekunan dalam belajar; (2) ulet dalam menghadapi kesulitan; (3) minat dalam belajar; (4) keinginan berhasil dalam belajar; (5) mandiri dalam belajar; (6) penghargaan.

Kreativitas siswa sangat diperlukan dalam proses pembelajaran. Kreativitas merupakan proses mental seseorang untuk memberikan solusi atas masalah yang ada, memberikan ide, konsep atau menciptakan produk yang dapat memberikan solusi untuk mengatasi permasalahan yang ada (Carter, 2007,p.152); Lau (2011,p.215) dan Adair (2007,p.8). Definisi lain kreativitas menurut Munandar (2002,p.33) adalah kemampuan untuk mencipta sesuatu yang baru, sebagai kemampuan untuk memberi gagasan baru yang dapat diterapkan dalam pemecahan masalah, atau sebagai kemampuan untuk melihat hubungan-hubungan baru antara unsur-unsur yang sudah ada sebelumnya.

Ciri-ciri siswa yang memiliki kreativitas adalah: (1) memiliki rasa ingin tahu yang tinggi; (2) belajar dengan penuh tanggung jawab; (3) mengambil keputusan secara cermat; (4) senang terhadap pemecahan masalah; dan (5) berwawasan luas.

Apabila PBM memperhatikan motivasi, kreativitas serta didukung oleh metode pembelajaran yang tepat maka akan menghasilkan hasil belajar yang optimal. Ranjan \& Rahman menyatakan bahwa hasil belajar menurut Bloom dibagi dalam tiga ranah, yaitu kognitif, afektif dan psikomotorik (http://www. dhsekarala.gov.in/download/role_tech.pdf). Tes afektif berkaitan dengan sikap, tes kognitif berkaitan dengan pengetahuan sedang tes psikomotorik berkaitan dengan keterampilan seseorang. Tes hasil belajar yang digunakan dalam penelitian ini meliputi tes kognitif dan tes psikomotorik.

Metode pembelajaran PBL merupakan metode pembelajaran yang berpusat pada 
siswa, siswa menemukan pengetahuannya dengan cara mengkonstruksi pengetahuannya sendiri. Sedangkan metode direct teaching berpusat pada guru, pengetahuan yang dibentuk bersifat sementara. Siswa yang memiliki motivasi tinggi akan selalu semangat dalam PBM sedangkan siswa yang memiliki motivasi rendah tidak memiliki gairah untuk belajar yang dapat mengakibatkan rendahnya hasil belajar siswa. Begitu pula siswa yang memilki kreativitas yang tinggi mereka akan selalu aktif untuk memecahkan permasalahan pembelajaran dari pada siswa yang memiliki kreativitas rendah.

Dari uraian yang telah dikemukakan, maka penelitian ini bertujuan untuk mengetahui: (1) perbedaan hasil belajar antara siswa yang diajar dengan metode PBL dan direct teaching, motivasi belajar tinggi dan rendah, kreativitas tinggi dan rendah; (2) pengaruh interkasi antara metode pembelajaran dengan motivasi belajar dan kreativitas terhadap hasil belajar; (3) perbedaan hasil belajar siswa yang diajar dengan metode PBL dan direct teaching ditinjau dari motivasi belajar dan kreativitas.

\section{METODE PENELITIAN}

\section{Jenis Penelitian}

Penelitian ini menggunakan pendekatan kuantitatif, karena dalam menganalisis data menggunakan angka-angka yang diolah dengan metode statistik. Setelah diperoleh hasilnya kemudian dideskripsikan dengan menguraikan kesimpulan yang didasari oleh angka yang diolah dengan metode statistik tersebut.

Jenis penelitian ini adalah penelitian eksperimen semu (quasy experiment) dengan desain faktorial yang dilakukan dengan memberikan perlakuan dalam bentuk metode pembelajaran.

\section{Tempat dan Waktu Penelitian}

Penelitian dilaksanakan di SMK Negeri 1 Ngawen Gunungkidul Yogyakarta yang beralamat di Jono, Tancep, Ngawen, Gunungkidul 55853. Waktu penelitian adalah semester genap tahun pelajaran 2012/2013 yaitu pada bulan Februari sampai April 2013.

\section{Populasi dan Sampel}

Populasi penelitian ini adalah siswa kelas $\mathrm{X}$ kompetensi keahlian teknik kendaraan ringan yang terdiri dari 4 kelas yaitu kela $X$ OA, X OB, X OC dan X OD. Pengambilan sampel dilakukan dengan teknik cluster random sampling. Teknik random dilakukan untuk memilih kelas yang dipilih menjadi sampel dengan undian, sedangkan cluster digunakan untuk memilih seluruh siswa pada kelas yang telah terpilih menjadi sampel. Sampel penelitian terdiri dari dua kelas yaitu kelas X OA yang diterapkan metode PBL dan kelas X OC diterapkan metode direct teaching.

\section{Prosedur}

Penelitian ini adalah quasy experiment dengan desain non-equivalent control group design.Pengambilan sampel kelas dilakukan secar random sedangkan siswa yang diambil dalam kelas sampel adalah seluruh siswa.

Desain ini melibatkan satu kelas eksperimen dan satu kelas kontrol. Kelas eksperimen menggunakan metode PBL dan kelas kontrol menggunakan metode direct teaching. Sebelum perlakuan dilaksanakan, dilakukan pengukuran motivasi belajar dan kreativitas siswa dengan menggunakan angket motivasi dan tes kreativitas. Sebelum diberi perlakuan dalam bentuk metode pembelajaran kedua kelompk diberi pretest dan setelah perlakuan metode pembelajaran kedua kelompok diberi posttest untuk mengetahui hasil belajar siswa.

Desain penelitian dalam penelitian ini dapat dilihat pada tabel 2.

Tabel 2. Desain Penelitian

\begin{tabular}{lccc}
\hline Kel. & Pretest & Perlakuan & Posttest \\
\hline $\mathrm{KE}$ & $\mathrm{O}_{1}$ & $\mathrm{X}_{1}$ & $\mathrm{O}_{2}$ \\
$\mathrm{KK}$ & $\mathrm{O}_{1}$ & $\mathrm{X}_{2}$ & $\mathrm{O}_{2}$ \\
\hline
\end{tabular}

Keterangan:

$\mathrm{KE}$ : Kelompok Eksperimen

KK : Kelompok Kontrol

$\mathrm{O}_{1}$ : Pretest, pengisian angket motivasi belajar dan tes kreativitas

$\mathrm{O}_{2}$ : Posttest

$\mathrm{X}_{1}$ : Metode Pembelajaran PBL

$\mathrm{X}_{2} \quad$ : Metode Pembelajaran direct teaching 


\section{Teknik dan Instrumen Pengumpulan Data}

Teknik pengumpulan data yang digunakan dalam penelitian ini adalah: (1) angket motivasi belajar yang digunakan untuk mengetahui tingkat motivasi belajar siswa; (2) tes hasil belajar yang terdiri dari tes teori dan tes praktek kompetensi menggunakan alat ukur. Tes teori berupa tes uraian mengenai materi alat ukur mekanik sedangkan tes praktek berupa tes unjuk kerja penggunaan alat ukur mekanik untuk mengukur komponen-komponen otomotif; (3) tes kreativitas, tes kreativitas yang digunakan dalam penelitian ini adalah tes kreativitas verbal yang telah distandarkan.

\section{Teknik Analisis Data}

Teknik analisis data yang digunakan dalam penelitian ini adalah: (1) uji kesamaan kemampuan awal; (2) uji statistik deskriptif; (3) uji prasyarat analisis; (4) uji hipotesis dengan Anava tiga jalur; dan (5) uji tindak lanjut dengan uji-t.

\section{HASIL PENELITIAN DAN PEMBAHASAN}

Uji kesamaan kemampuan awal dilakukan untuk mengetahui apakah kedua kelompok dalam keadaan sama atau tidak. Hasil uji kesamaan kemampuan dapat dilihat pada tabel 3.

Tabel 3.Hasil Uji Kesamaan Kemampuan Awal

\begin{tabular}{lccl}
\hline Data & $\mathbf{F}_{\text {hit. }}$ & Sig. & Keputusan \\
\hline Pretest & 0,051 & 0,882 & $\begin{array}{l}\text { Kemampuan awal } \\
\text { sama }\end{array}$ \\
\hline
\end{tabular}

Sebelum dilakukan uji hipotesis dilakukan uji prasyarat analisis. Uji prasyarat analisis meliputi normalitas dan homogenitas. Hasil uji prasyarat analisis dapat dilihat pada tabel 4 .

Tabel 4. Hasil Uji Prasyarat Analisis

\begin{tabular}{ll}
\hline Data & Keputusan \\
\hline Hasil Belajar & Normal dan Homogen \\
Motivasi & Normal dan Homogen \\
Kreativitas & Normal dan Homogen \\
\hline
\end{tabular}

Uji hipotesis yang digunakan dalam penelitian ini menggunakan uji Anava tiga jalur dan uji-t. Rangkuman hasil uji beda dengan Anava dapat dilihat pada tabel 5.
Tabel 5. Rangkuman Uji Beda dengan Anava

\begin{tabular}{lcl}
\hline Data & Sig. & Keputusan \\
\hline PBL x DT & 0,000 & Ada perbedaan \\
MT x MR & 0,652 & Tida ada perbedaan \\
KT x KR & 0,039 & Ada perbedaan \\
\hline
\end{tabular}

Keterangan:

PBL : Problem-Based Learning

DT : Direct Teaching

MT : Motivasi Tinggi

MR : Motivasi Rendah

KT : Kreativitas Tinggi

KR : Kreativitas Rendah

Sedangkan rangkuman hasil uji interaksi dengan Anava dapat dilihat pada tabel 6 .

Tabel 6. Rangkuman Uji Interaksi dengan Anava

\begin{tabular}{lll}
\hline Data & Sig. & Keputusan \\
\hline Metode*Motivasi & 0,000 & Ada interaksi \\
Metode*Kreativitas & 0,015 & Ada interaksi \\
\hline
\end{tabular}

Uji tindak lanjut dengan uji-t dapat dilihat pada tabel 7.

Tabel 7. Rangkuman Uji-T

\begin{tabular}{|c|c|c|}
\hline Data & Sig. & Keputusan \\
\hline PBLMR x DTMR & 0,000 & Ada perbedaan \\
\hline PBLMT x DTMT & 0,126 & $\begin{array}{l}\text { Tidak ada } \\
\text { perbedaan }\end{array}$ \\
\hline PBLKR x DTKR & 0,000 & Ada perbedaan \\
\hline PBLKT x DTKT & 0,109 & $\begin{array}{l}\text { Tidak ada } \\
\text { perbedaan }\end{array}$ \\
\hline
\end{tabular}

Keterangan:

PBLMR : PBL Motivasi Rendah

DTMR : DT Motivasi Rendah

PBLMT : PBL Motivasi Tinggi

DTMT : DT Motivasi Tinggi

PBLKR : PBL Kreativitas Rendah

DTKR : DT Kreativitas Rendah

PBLKT : PBL Kreativitas Tinggi

DTKT : DT Kreativitas Tinggi

\section{Perbedaan Hasil Belajar Siswa yang Diajar dengan Metode PBL dan Direct Teaching}

Hasil pengujian hipotesis pertama menunjukkan bahwa ada perbedaan yang signifikan hasil belajar alat ukur antara siswa 
yang diajar dengan metode PBL dan metode direct teaching. Perhitungan data tes hasil belajar alat ukur menunjukkan bahwa siswa yang diajar dengan metode PBL memperoleh skor rata-rata 78,42 lebih tinggi bila dibandingkan dengan siswa yang diajar dengan metode direct teaching yang skor rata-ratanya sebesar 74,07. Data ini menunjukkan bahwa penerapan metode PBL terbukti mempunyai pengaruh yang lebih baik terhadap hasil belajar kompetensi alat ukur dibandingkan dengan metode direct teaching.

Metode PBL menitikberatkan pada aktivitas siswa yang dilandasi oleh pandangan konstruktivistik, di mana siswa mengkonstruksi pengetahuannya dengan belajar bermakna. Aktivitas siswa pada metode PBL dimulai dengan orientasi pada permasalahan kemudian siswa dituntut untuk menjawab permasalahan tersebut. Siswa dituntut untuk aktif membaca, mencari informasi dari internet atau buku, berdiskusi dengan teman dan mempraktekkan pada benda yang sesungguhnya baik secara mandiri maupun kelompok. Siswa ketika praktek tidak hanya membaca jobsheet yang diberikan, akan tetapi siswa menganalisis terlebih dahulu permasalahan yang muncul kemudian mencari alternatif pemecahan masalahnya sehingga pembelajaran berjalan lebih efektif dan bermakna.

Siswa merekonstruksi pengetahuan secara mandiri selama proses pembelajaran. Pembelajaran PBL juga menuntut adanya kerja kelompok dan diskusi yang dilanjutkan dengan presentasi mengenai hasil temuan ketika melaksanakan penyelidikan, pada bagian ini siswa akan saling membantu dalam menguasai pelajaran. Siswa akan melakukan tanya jawab dengan bahasa mereka sendiri tanpa rasa sungkan. Siswa yang pintar akan merasa dihargai, karena diberi kesempatan untuk membimbing temannya, sedangkan siswa yang kurang paham akan lebih mudah bertanya kepada temannya yang lebih tahu tanpa rasa sungkan. Hal ini tentu akan memotivasi siswa kelas PBL sehingga akan menghasilkan hasil belajar kompetensi menggunakan alat ukur yang lebih baik.

Pembelajaran PBL mampu meningkatkan keaktifan, perhatian dan kerja sama antar siswa. Dominasi guru semakin berkurang sedangkan peran aktif siswa semakin bertambah. Tingginya aktifitas dan perhatian siswa akan meningkatkan kemampuan siswa dalam mengeksplorasi pelajaran. Siswa akan lebih aktif untuk mencari informasi sebagai bahan pembahasan permasalahan dan diskusi. Siswa berusaha untuk mencari informasi dari berbagai sumber seperti informasi dari internet, buku-buku referensi, manual book kendaraan, atau bertanya kepada guru. Partisipasi dan kerja sama akan mengefektifkan proses elaborasi dalam pembelajaran. Elaborasi adalah proses penguatan dan pendalaman penguasaan materi pelajaran. Karena partisipasi dan kerja sama siswa akan saling memberi dan menerima informasi sehingga materi yang didapatkan semakin lengkap.

Pembelajaran PBL dapat merangsang motivasi selama pembelajaran yang akhirnya dapat meningkatkan hasil belajar. Ketika pembelajaran berlangsung, siswa yang diajar dengan metode PBL sangat antusias dalam pembelajaran. Mereka aktif untuk belajar, kelas tampak gaduh akan tetapi gaduh dalam hal positif karena mereka saling beradu argumen dalam mempelajari materi dan memecahkan masalah pembelajaran. Siswa sangat serius dalam kegiatan pembelajaran praktek dari awal sampai akhir dan mereka memanfaatkan waktu dengan baik. Sedangkan siswa yang diajar dengan metode direct teaching pada saat pembelajaran praktek mereka hanya serius pada awal saja, hanya berpedoman langkah-langkah yang ada di jobsheet tanpa ada inovasi langkah-langkah praktek yang lebih efektif. Setelah data praktek didapatkan mereka cenderung pasif karena menganggap praktek sudah selesai, tanpa menganalisis data hasil praktek. Hal ini menunjukkan bahwa metode direct teaching cocok untuk materi yang bersifat sederhana dan testruktur, akan tetapi tidak cocok untuk materi yang bersifat kompleks, analisis dan pemecahan masalah.

\section{Perbedaan Hasil Belajar antara Siswa yang Memiliki Motivasi Belajar Tinggi dan Rendah}

Pengujian hipotesis kedua menunjukkan bahwa tidak ada perbedaan yang signifikan hasil belajar alat ukur antara siswa yang memiliki motivasi belajar tinggi dan motivasi 
belajar rendah. Siswa yang memiliki motivasi belajar tinggi memperoleh rata-rata hasil belajar yang lebih tinggi dari pada siswa yang memiliki motivasi belajar rendah. Akan tetapi perbedaan hasil belajar tersebut tidak berbeda secara signifikan. Kelompok siswa yang memiliki motivasi belajar tinggi memperoleh skor rata-rata 76,60 sedangkan kelompok siswa yang memiliki motivasi belajar rendah memperoleh skor rata-rata sebesar 75,70.

Secara teori, siswa yang memiliki motivasi belajar tinggi akan mendapatkan hasil belajar yang tinggi pula. Siswa yang memiliki motivasi belajar tinggi akan memperoleh hasil belajar yang lebih baik dibandingkan dengan siswa yang memiliki motivasi belajar rendah.

Penelitian ini juga menunjukkan adanya peningkatan hasil belajar antara siswa yang memiliki motivasi belajar tinggi dan motivasi belajar rendah. Siswa yang memiliki motivasi belajar rendah rata-rata skor pada saat pretest sebesar 39,26 dan pada saat posttest meningkat menjadi 75,70 . Sedangkan siswa yang memiliki motivasi belajar tinggi rata-rata skor pada saat pretest adalah 39,81 dan pada saat posttest meningkat menjadi 76,60.

Walaupun dalam penelitian ini menunjukkan adanya peningkatan hasil belajar antara siswa yang memiliki motivasi belajar tinggi dan motivasi belajar rendah, akan tetapi tidak ada perbedaan yang signifikan hasil belajar alat ukur antara siswa yang memiliki motivasi belajar tinggi dan motivasi belajar rendah. Hal ini menunjukkan ada faktor lain yang berpengaruh terhadap hasil belajar. Faktor tersebut adalah metode pembelajaran yang diterapkan dalam penelitian, yaitu metode PBL dan direct teaching.

\section{Perbedaan Hasil Belajar antara Siswa yang Memiliki Kreativitas Tinggi dan Rendah}

Pengujian hipotesis ketiga menunjukkan bahwa terdapat perbedaan yang signifikan hasil belajar alat ukur antara siswa yang memiliki kreativitas tinggi dan kreativitas rendah. Siswa yang memiliki kreativitas tinggi memiliki hasil belajar yang lebih baik dari pada siswa yang memiliki kreativitas rendah. Hasil analisis data menunjukkan bahwa kelompok siswa yang memiliki kreativitas tinggi memiliki skor rata- rata 77,06 dan kelompok siswa yang memiliki kreativitas rendah diperoleh skor rata-rata sebesar 75,28.

Penelitian ini menunjukan bahwa faktor kreativitas terbukti mempunyai pengaruh yang signifikan dalam membantu meningkatkan hasil belajar alat ukur. Seseorang yang memiliki kreativitas berusaha menemukan hal yang baru, atau memodifikasi hal-hal yang sudah ada menjadi lebih bermanfaat. Adanya keinginan siswa untuk mengembangkan potensinya menjadi pendorong siswa memanfaatkan kreativitasnya mengetahui hal-hal yang baru. Kondisi tersebut memberikan pengaruh yang signifikan terhadap hasil belajar.

Setiap siswa memiliki tingkat kreativitas yang berbeda-beda. Siswa yang memiliki kreativitas tinggi cenderung memiliki rasa ingin tahu yang tinggi, belajar dengan penuh percaya diri, dapat mengambil keputusan secara cermat, senang terhadap pemecahan masalah, berwawasan luas (berpikir divergen), dalam menghadapi masalah memiliki banyak alternatif pemecahan, dan memiliki keyakinan yang kuat terhadap keberhasilan belajarnya. Keyakinan yang kuat dan penuh percaya diri terhadap keberhasilan belajar sebagai modal dasar bagi siswa dalam meraih hasil yang lebih baik.

Siswa yang memiliki kreativitas rendah, cenderung tidak dapat melihat masalah dan informasi dengan jelas, berpola pikir linier, mudah menyerah, tidak percaya diri dan tidak memiliki pendirian dan keyakinan yang kuat, tidak berani mengambil resiko, dan tidak bisa mengambil keputusan. Dengan pola pemikiran ini, siswa tidak terbiasa berpikir untuk menemukan banyak alternatif dalam memahami setiap persoalan yang dihadapi, rasa ingin tahu rendah dan kurang percaya diri, sehingga jika satu altenatif yang dianggap benar diterapkan dalam praktek memahami permasalahan dan cara pemecahannya ternyata tidak berhasil, maka siswa putus asa. Siswa cenderung memiliki rasa ingin tahu yang secara tekstual, berpikir sesuai dengan situasi dan kondisi masalah yang dihadapi. Kondisi tersebut sangat mempengaruhi dalam pencapaian hasil belajar. Siswa yang memiliki kreativitas rendah cenderung memperoleh hasil belajar yang kurang optimal. 


\section{Interaksi antara Metode Pembelajaran dengan Motivasi Belajar terhadap Hasil Belajar}

Pengujian hipotesis keempat menunjukkan bahwa ada pengaruh interaksi antara metode pembelajaran dengan motivasi belajar terhadap hasil belajar alat ukur. Hasil ini menunjukkan hasil belajar tidak hanya dipengaruhi oleh metode pembelajaran saja akan tetapi juga dipengaruhi oleh motivasi belajar. Motivasi belajar mempengaruhi keefektifan penerapan metode pembelajaran yang berbasis pada siswa (student centered).

Metode PBL merupakan metode pembelajaran yang menuntut keaktifan siswa dalam proses pembelajaran melalui serangkaian kegiatan penelitian dan praktek. Siswa diorganisasikan dalam kelompok kooperatif dari berbagai macam latar belakang yang berbeda. Kelompok yang heterogen ini kemudian bekerja sama secara kolaboratif untuk menemukan masalah dan memecahkan masalah secara bersama-sama. Siswa membaca, mencari informasi melalui internet, manual training, berdiskusi, menyelidiki, mempraktekkan pengukuran pada komponenkomponen otomotif, dan hasil penemuan dan pemecahan masalahnya dipresentasikan di depan kelas. Kondisi ini menuntut siswa untuk memiliki motivasi belajar tinggi agar proses pembelajaran dapat berlangsung dengan baik.

Uraian di atas dapat disimpulkan bahwa metode pembelajaran dan motivasi belajar sama-sama memberikan pengaruh terhadap hasil belajar kompetensi menggunakan alat ukur. Untuk itu dalam penerapan pembelajaran di kelas perlu memperhatikan motivasi belajar siswa. Guru harus mampu membangkitkan motivasi belajar siswa agar pembelajaran dapat berlangsung secara efektif yang pada akhirnya dapat meningkatkan hasil belajar siswa.

\section{Interaksi antara Metode Pembelajaran dengan Kreativitas Siswa terhadap Hasil Belajar}

Pengujian hipotesis kelima menyimpulkan bahwa adainteraksi antara metode pembelajaran dengan kreativitas siswa terhadap hasil belajar alat ukur. Hasil ini menunjukkan bahwa hasil belajar tidak hanya dipengaruhi oleh metode pembelajaran saja, akan tetapi juga dipengaruhi oleh kreativitas siswa. Kreativitas mempengaruhi keefektifan penerapan metode pembelajaran terutama metode pembelajaran yang menfasilitasi siswa untuk belajar melalui kegiatan penemuan masalah, analisis permasalahan, penyelidikan, presentasi dan refleksi, serta proses integrasi dan evaluasi. Kondisi tersebut sangat mendukung dalam penerapan metode pembelajaran PBL. Metode PBL menfasilitasi siswa untuk belajar melalui kegiatan menemukan masalah, menganalisis permasalahan, melakukan penyelidikan untuk mengatasi masalah, melakukan presentasi dan refleksi, serta proses integrasi dan evaluasi.

Hasil penelitian ini memperkuat pendapat Tan (2003,p.35), Arends (2008,p.42), Liu, Liau \& Tan (2009,p.206) bahwa pembelajaran PBL lebih mengutamakan keterlibatan siswa secara aktif dalam pembelajaran. Dalam implementasinya guru memberikan orientasi permasalahan, mengorganisasi siswa untuk meneliti, membantu investigasi mandiri dan kelompok, mempresentasikan artefak, menganalisis dan mengevaluasi proses pemecahan masalah. Penerapan metode PBL memerlukan kemampuan siswa dalam melihat permasalahan,informasi dan data secara cermat, dan pemikiran yang divergen (kreativitas) sehingga siswa memiliki pengetahuan dan pengalaman secara komprehensif. Kreativitas siswa dalam memahami masalah, menemukan informasi, dan memberikan solusi masalah dalam pembelajaran sangat mempengaruhi tingkat pencapaian hasil belajar.

Faktor-faktor yang mempengaruhi terjadinya interaksi antara metode pembelajaran (PBL dan direct teaching) dengan tingkat kreativitas siswa antara lain: (1) langkahlangkah penerapan metode PBL memberikan kesempatan yang luas pada siswa yang memiliki kreativitas tinggi untuk menguasai materi pelajaran. Langkah-langkah pembelajaran tersebut, meliputi: guru menjelaskan prosedur pembelajaran kepada siswa, guru menyajikan masalah pada siswa, siswa mengumpulkan data dengan melakukan eksperimen untuk mencari penjelasan dan solusi, siswa membuat bukti penyelidikan untuk dipresentasikan, dan siswa membuat kesimpulan dari hasil 
pembelajaran bersama guru. Langkah-langkah tersebut menuntut partisipasi aktif dari siswa; (2) proses pembelajaran PBL menuntut siswa untuk belajar secara kolaboratif dalam menemukan masalah, mencari informasi, dan menemukan solusi permasalahan yang terkait dengan materi pelajaran. Siswa dituntut untuk berpikir kritis dan kreatif. Hal ini mendorong siswa yang memiliki kreativitas tinggi dapat menemukan berbagai alternatif pemecahan masalah sebagai jawab permasalahan yang diajukan; (3) materi kompetensi menggunakan alat ukur (measuring tools) yang berisi sejumlah materi berupa pengetahuan dasar, pembacaan hasil pengukuran, praktek penggunaan alat ukur, dan menganalisis hasil pengukuran memerlukan kreatifitas berpikir siswa. Siswa harus cepat tanggap untuk menyelesaikan permasalahan yang dihadapi baik itu soal teori maupun praktek.

Evaluasi belajar dalam penelitian ini dilakukan dalam bentuk tes teori dan praktek. Tes teori berbentuk uraian sehingga siswa dituntut untuk lebih kreatif dalam mengungkapkan idenya sesuai dengan pengetahuan yang dibentuk selama proses pembelajaran. Tes praktek yang diberikan juga menuntut kreativitas siswa, pemahaman konsep terhadap materi dan tidak hanya bersifat hafalan.

\section{Perbedaan Hasil Belajar Siswa yang Diajar dengan Metode PBL dan Direct Teaching ditinjau dari Motivasi Belajar}

Hasil uji hipotesis keenam menunjukkan ada perbedaan yang signifikan hasil belajar kompetensi menggunakan alat ukur antara siswa yang diajar dengan metode PBL dan direct teaching ditinjau dari motivasi belajar rendah. Siswa yang memiliki motivasi belajar rendah diajar dengan metode PBL hasilnya lebih baik daripada diajar dengan metode direct teaching. Artinya siswa yang memiliki motivasi belajar rendah hasilnya akan lebih efektif bila diajar dengan metode PBL.

Uji hipotesis keenam juga menunjukkan bahwa tidak ada perbedaan yang signifikan hasil belajar kompetensi menggunakan alat ukur antara siswa yang diajar dengan metode PBL dan direct teaching ditinjau dari motivasi belajar tinggi. Siswa yang memiliki motivasi tinggi diajar dengan metode PBL maupun direct teaching hasil belajarnya sama-sama baik. Artinya siswa yang memiliki motivasi belajar tinggi hasilnya akan lebih efektif bila diajar dengan metode PBL maupun direct teaching.

Siswa yang memiliki motivasi belajar tinggi akan lebih bersemangat dalam kegiatan pembelajaran. Siswa yang memiliki motivasi belajar tinggi memiliki ciri-ciri sebagai berikut: (1) tekun terhadap tugas; (2) ulet menghadapi kesulitan; (3) menunjukkan minat terhadap bermacam-macam masalah; (4) belajar secara mandiri; (5) menyukai kegiatan variatif; (6) dapat berargumen dan pantang menyerah; (7) tidak mudah menyerah; dan (8) menyukai pemecahan masalah.

Karakteristik siswa di atas sangat mendukung penerapan metode pembelajaran PBL yang menuntut siswa untuk mengkonstruk pengetahuannya sendiri dengan memecahkan masalah untuk meningkatkan pengetahuan dan pemahaman siswa terhadap materi pelajaran. Metode pembelajaran PBL dapat meningkatkan motivasi belajar siswa selama proses pembelajaran, karena dalam pembelajaran PBL guru mendesain pembelajaran dengan permasalahan yang dekat dengan dunia nyata siswa dan siswa harus terlibat aktif dalam pemecahan masalah tersebut.

Siswa diorganisasikan dalam kelompok kooperatif dari berbagai macam latar belakang yang berbeda, baik kemampuan akademik, motivasi, kreativitas, latar belakang keluarga dan lain sebagainya. Kelompok yang heterogen ini kemudian bekerja sama secara kolaboratif untuk menemukan masalah dan memecahkan masalah secara bersama-sama. Siswa membaca, mencari informasi melalui internet, manual training, berdiskusi, menyelidiki, mempraktekkan pengukuran pada komponenkomponen otomotif, dan hasil penemuan dan pemecahan masalahnya dipresentasikan di depan kelas. Siswa yang memiliki kemampuan rendah dan motivasi rendah akan terdorong untuk aktif, bertanya tanpa rasa sungkan dan terdorong untuk mencapai hasil yang terbaik. Hal inilah yang menyebabkan metode pembelajaran PBL cocok untuk diterapkan pada siswa yang memiliki motivasi tinggi maupun rendah. 


\section{Perbedaan Hasil Belajar Siswa yang diajar dengan Metode PBL dan Direct Teaching ditinjau dari Kreativitas Siswa}

Hasil uji hipotesis ketujuh menunjukkan ada perbedaan yang signifikan hasil belajar alat ukur antara siswa yang diajar dengan metode PBL dan direct teaching ditinjau dari kreativitas rendah. Siswa yang memiliki kreativitas rendah diajar dengan metode PBL hasilnya lebih baik daripada diajar dengan metode direct teaching. Artinya siswa yang memiliki kreativitas rendah hasilnya akan lebih efektif bila diajar dengan metode PBL.

Uji hipotesis ketujuh juga menunjukkan bahwa tidak ada perbedaan yang signifikan hasil belajar alat ukur antara siswa yang diajar dengan metode PBL dan direct teaching ditinjau dari kreativitas tinggi. Siswa yang memiliki kreativitas tinggi diajar dengan metode PBL maupun direct teaching hasil belajarnya sama-sama baik. Artinya siswa yang memiliki kreativitas tinggi hasilnya akan lebih efektif bila diajar dengan metode PBL maupun direct teaching.

Sifat-sifat positif yang dimiliki oleh siswa yang memiliki kreativitas tinggi mendukung penerapan pembelajaran metode PBL. Materi alat ukur yang diajar menggunakan metode PBL memerlukan kemampuan berpikir kritis, solutif dan kreatif dalam memecahkan masalah. Metode PBL baik diterapkan pada siswa yang memiliki kreativitas tinggi maupun rendah. Siswa yang memiliki kreativitas tinggi tentu akan menghasilkan hasil belajar yang baik karena sifat yang dimiliki menjadi tuntutan dalam pembelajaran PBL. Sedangkan siswa yang memiliki kreativitas rendah juga lebih efektif diajar dengan metode PBL daripada direct teaching. Siswa yang memiliki kreativitas rendah akan terbawa efek dari metode pembelajaran metode PBL yang menuntut siswa untuk mencari tahu, berpikir kritis, kreatif dan gigih untuk mencapai tujuan pembelajaran.

\section{SIMPULAN DAN SARAN}

\section{Simpulan}

Berdasarkan hasil penelitian, analisis data serta pembahasan maka dapat diambil kesimpulan sebagai berikut: (1) terdapat perbedaan hasil belajar antara siswa yang diajar dengan metode PBL dan direct teaching. Hasil belajar siswa yang diajar dengan metode PBL lebih tinggi dibanding dengan siswa yang diajar dengan metode direct teaching dan berbeda secara signifikan; (2) tidak dapat perbedaan hasil belajar antara siswa yang memiliki motivasi belajar tinggi dan rendah. Hasil belajar siswa yang memiliki motivasi belajar tinggi lebih baik dibanding dengan siswa yang memiliki motivasi belajar rendah, akan tetapi perbedaannya tidak signifikan; (3) terdapat perbedaan hasil belajar antara siswa yang memiliki kreativitas tinggi dan rendah. Hasil belajar siswa yang memiliki kreativitas tinggi lebih baik dibanding dengan siswa yang memiliki kreativitas rendah dan berbeda secara signifikan; (4) terdapat perbedaan hasil belajar antara siswa yang diajar dengan metode PBL dan direct teaching ditinjau dari motivasi belajar rendah. Tidak terdapat perbedaan hasil belajar siswa yang diajar dengan metode PBL dan direct teaching ditinjau dari motivasi belajar tinggi. Siswa yang memiliki motivasi belajar rendah lebih baik diajar dengan metode PBL, sedangkan siswa yang memiliki motivasi belajar tinggi dapat diajar dengan metode PBL maupun direct teaching; (5) terdapat perbedaan hasil belajar antara siswa yang diajar dengan metode PBL dan direct teaching ditinjau dari kreativitas rendah. Tidak terdapat perbedaan hasil belajar antara siswa yang diajar dengan metode PBL dan direct teaching ditinjau dari kreativitas tinggi. Siswa yang memiliki kreativitas rendah lebih baik diajar dengan metode PBL, sedangkan siswa yag memiliki kreativitas tinggi dapat diterapkan metode PBL maupun direct teaching.

\section{Implikasi}

Berdasarkan hasil penelitian dan simpulan, implikasi hasil penelitian ini adalah sebagai berikut: (1) penggunaan metode pembelajaran PBL memiliki pengaruh dalam upaya pencapaian kompetensi siswa baik secara teori maupun praktek, sehingga perlu diimplementasikan dalam kegiatan pembelajaran di kelas; (2) guru perlu memperhatikan motivasi belajar dan kreativitas siswa dalam kegiatan pembelajaran. Motivasi 
belajar dan kreativitas ini perlu dioptimalkan dalam rangka mencapai hasil belajar yang lebih baik. Siswa yang memiliki motivasi belajar tinggi dan kreativitas tinggi terbukti dapat mencapai hasil belajar yang tinggi pula; (3) Penggunaan metode pembelajaran dapat digunakan untuk meningkatkan hasil belajar baik teori maupun praktek untuk materi yang memiliki karakteristik sama dengan kompetensi menggunakan alat ukur dengan tetap memperhatikan motivasi belajar dan kreativitas siswa; (4) metode pembelajaran PBL dapat diterapkan kepada siswa yang memiliki motivasi belajar tinggi maupun rendah dan siswa yang memiliki kreativitas tinggi maupun rendah.

\section{Saran}

Berdasarkan kesimpulan hasil penelitian, berikut saran untuk meningkatkan hasil belajar siswa.

1. Guru

(a) guru yang mengajar alat ukur SMK jurusan otomotif dapat menerapkan metode PBL karena telah terbukti meningkatkan hasil belajar siswa; (b) guru hendaknya memperhatikan motivasi belajar siswa dalam menerapkan metode pembelajaran. Siswa yang memiliki motivasi belajar tinggi dapat diterapkan metode PBL maupun directteaching, sedangkan siswa yang memiliki motivasi belajar rendah lebih baik diajar dengan metode PBL; (c) guru hendaknya juga memperhatikan kreativitas siswa dalam menerapkan metode pembelajaran. Siswa yang memiliki kreativitas tinggi dapat diterapkan metode PBL maupun direct teaching, sedangkan siswa yang memiliki kreativitas rendah lebih baik diajar dengan metode PBL.

\section{Sekolah}

Pihak sekolah diharapkan membudayakan penerapan metode pembelajaran PBL atau inovasi metode pembelajaran lainnya kepada guru melalui kegiatan workshop, training atau lesson study. Selain itu juga dapat menyediakan saran dan prasarana yang dapat mendukung pelaksanaan pembelajaran PBL.

\section{Peneliti Selanjutnya}

Peneliti selanjutnya diharapkan mengembangkan dan menyempurnakan penelitian ini. Penelitian dapat diterapkan pada mata pelajaran produktif lainnya yang diajarkan di SMK.

\section{DAFTAR PUSTAKA}

Adair, John. (2007). The art of creative thinking. How to be innovative and develop great ideas. London and Philadelphia: Kogan Page.

Arends, Richard I. (2008). Learning to teach, belajar untuk mengajar. Edisi ketujuh (Terjemahan Helly Prayitno S \& Sri Mulyantini S). New York: McGraw Hill Companies. (Buku asli diterbitkan tahun 2007).

Baden, M. Savin \& Major, C. Howell.(2004). Fondation of problem-based learning. New York: McGraw-Hill

Carter, Philip. (2007). IQ and personality test. London and Philadelphia: Kogan Page.

Edgar, D. W., et al. (2008). Creative thinking: opening up a world of thought. [Versi elektronik]. Techniques Journal, April 2008,83,4, ProQuest Educational Journals. Pg. 46.

Finch, Curtis R. \& Crunkilton, John R., (1999). Curriculum development in vocational and technical education: planning, content, and implementation ( $5^{\text {th }} \mathrm{ed}$.). Boston: Allyn and Bacon, Inc.

Galton, et al. (2009). Motivatingyour secondary class. Los Angeles: Sage Publicatations.

Guthrie, J.W. \& Schuermann, P.J. (2011). Leading schools to succes: constructing and sustaining high performing learning culture. Los Angeles: SAGE Publication, Inc.

Isaksen, Scott. G., Dorval, K. Brian., \& Treffinger, Donald. J. (2011). Creative approaches to problem solving: a framework fo innovation and change. ( $3^{\text {rd }} e d$.). Los Angeles: SAGE Publication, Inc.

Joyce, B., Weil, M. \& Calhoun, E. (2009). Model of teaching. Boston: Prentice Hall. 
Lau, Joe Y. F. (2011). An introduction to critical thinking and creativity. Think more, think better. Hoboken: John Wiley \& Son, Inc.

Liu, W. C., Liau, A. K., \& Tan, O. S. (2009). E-portofolios for problem-based learning: scaffolding thinking and learning in preservice teacher education. Dalam Tan, O.S. (Ed.). Problem-based learning and creativity (pp. 205-223). Singapore: Cengage Learning Asia Pte Ltd.

Marsh, Colin J. (2010). Becoming a teacher: knowledge, skills and issues. (5th ed.). French Forest: Pearson Australia.

McLean, Alan. (2009). Motivating every learner. Los Angeles: Sage Publication.

Munandar, U. S. C. (2002). Kreativitas \& keberbakatan. Strategi mewujudkan potensi kreatif \& bakat. Jakarta: PT Gramedia Pustaka Utama

Parkay, Forrest A. \& Stanford, Beherly H. (2010). Becoming a teacher, ( $8^{\text {th }}$ ed.). Upper Saddle River: Pearson Education, Inc.

Ranjan, N. \& Rahman, N. Role of teacher in enhacncing learning achievement of child \& emphasis on teacher skill development, knowledge building and ICT.http://dhsekerala.gov.in/downloads/ role_tech.pdf. Diakses tanggal 10 Agustus 2013.
Sardiman, A. M. (2011). Interaksi dan motivasi belajar mengajar. Jakarta: PT. Raja Grafinddo Persada.

Suprijono, Agus. (2010). Cooperative learning, teori dan aplikasi PAIKEM. Yogyakarta: Pustaka Pelajar. Diakses dari http:// history22education.wordpress.com tanggal 15 Agustus 2012

Tan, O. S. (2003). Problem-based learning innovation, using problems to power learning in the $21^{\text {st }}$ century. Singapore: Cengage Learning Asia Pte Ltd.

Tan, O. S., Teo, C. T., \& Chye, Stefanie. (2009). Problem and creativity. Dalam Tan, O.S. (Ed.). Problem-based learning and creativity (pp. 1-13). Singapore: Cengage Learning Asia Pte Ltd.

Wong, H. K. \& Wong, R. T. (2005). How to be an effective teacher: the first days of school. Montain View: Harry K. Wong Publication, Inc.

Wood, F. D. What is problem learning?. http:// www.bmj.com/content/326/ 7384/328. Diakses 10 Agustus 2012.

Woolfolk, A. (2007). Educational psychology. Boston: Pearson Education, Inc. 